RESEARCH ARTICLE

\title{
CONFLICTING INTERESTS OF LEGISLATORS IN INDIA: AN EXPLORATORY STUDY
}

\author{
Deb Zyoti Das ${ }^{1 凶}$, Bhanu Singh Rohilla ${ }^{2}$ \\ 1,2 Himachal Pradesh National Law University, India \\ $\triangle$ debdas350@gmail.com
}

\section{CITED AS}

Das, D. Z., \& Rohilla, B. S. (2020). Conflicting Interests of Legislators in India: An Exploratory Study. Journal of Law and Legal Reform, 1(4), 605-616. https://doi.org/10.15294/jllr.vli4.39867

\begin{abstract}
Law governs society and evolves with it as time progresses. The process of evolution is a complex, continuous and an integrated cycle of different, moving spheres of life. With the evolution of society, there arises a need for laws to govern the new behaviors generated by such evolution. Hence, law-making bodies such as parliaments of countries and states move and aspire to regulate; and mold the behavior of their subjects and citizens in order to avoid, resolve and suppress chaos and maintain the proper and smooth functioning of the society at hand. Persons involved in the lawmaking process are also party to the society and hence influenced by their circles and spheres of society. The interests of a particular legislator could be varied enough to put a significant effect on the piece of legislation he is working on that will, in future most probably guide the whole nation. With the party based Indian politics, it becomes more difficult for a legislator to serve the interests of the nation before the command and interests of the political party that the Legislator represents. It is thus imperative for us to understand the difficulties and constraints that a legislator face when he drafts or prepares Legislation or is involved in a law-making process. This article explores and describes the scenario in India elaborately.
\end{abstract}

Keywords: Conflict of Interest; Legislator; Political Party; Indian Politics 


\section{TABLE OF CONTENTS}

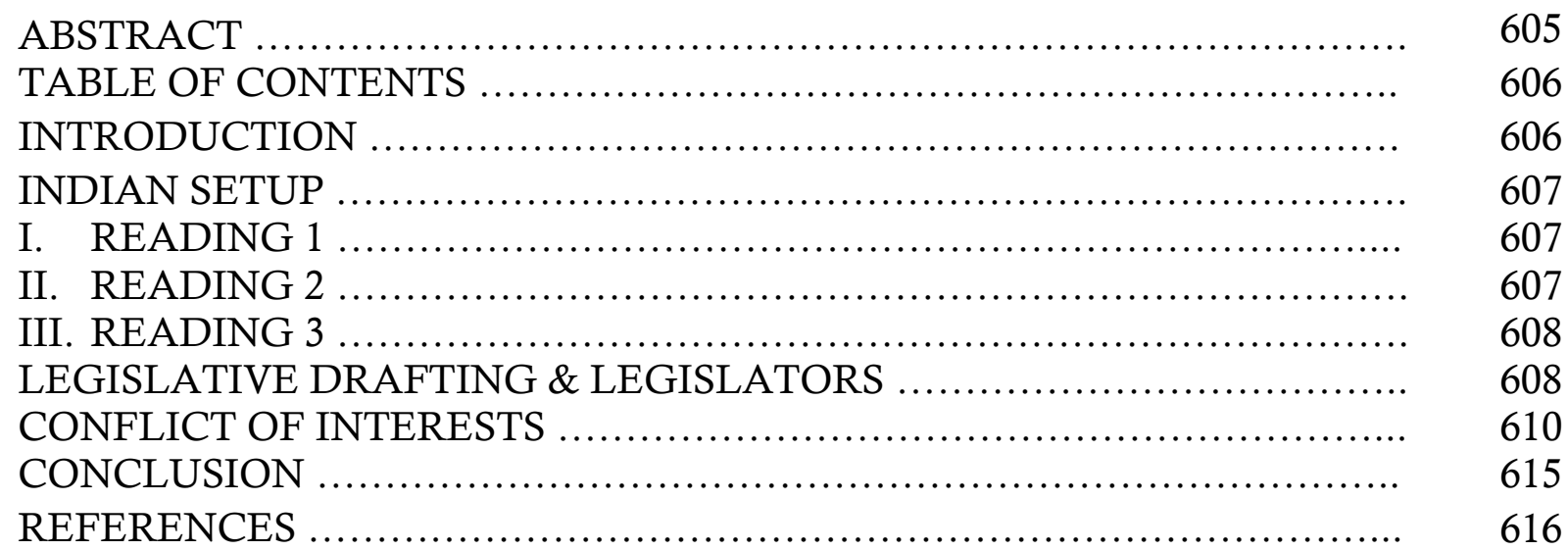

\section{INTRODUCTION}

Law governs society and evolves with it as time progresses. The process of evolution is a complex, continuous and an integrated cycle of different, moving spheres of life. With the evolution of society, there arises a need for laws to govern the new behaviors generated by such evolution. Hence, law-making bodies such as parliaments of countries and states move and aspire to regulate; and mold the behavior of their subjects and citizens in order to avoid, resolve and suppress chaos and maintain the proper and smooth functioning of the society at hand.

Persons involved in the law-making process are also party to the society and hence influenced by their circles and spheres of society. The interests of a particular legislator could be varied enough to put a significant effect on the piece of legislation he is working on that will, in future most probably guide the whole nation. With the party based Indian politics, it becomes more difficult for a legislator to serve the interests of the nation before the command and interests of the political party that the Legislator represents. It is thus imperative for us to understand the difficulties and constraints that a legislator face when he drafts or prepares Legislation or is involved in a law-making process. 


\section{INDIAN SETUP}

It is a well-known fact that Laws are made for the social needs, improvement of society and to remove illegal practices and other social problems. In India, our Constitution provides the law-making procedure in the Indian Parliament or Legislation. The primary function of the Parliament is to make, new laws and to revise or abrogate existing laws. However, sometimes the laws are subject to Judicial Review.

The process of drafting Legislation gets started with the need for any new law or need of amendment in any existing law. It may be done by the Government or by people's groups who are living in society and who can swell public awareness in regards to the entail of law.

After the requirement of law, the concerned Ministry drafts a 'bill' which is containing the desired law. This Bill is disseminated to other relevant ministries for modifications and changes they deem fit in it. It is also induced to the public to take comments from the people. The draft is reappraised to subsume any modifications or changes and is then whetted by Law Ministry, after that it presented to the Cabinet for approval. When the Cabinet approves the Bill, it is introduced in either House of the Parliament. Now there are 3 Readings of the Bill in both the houses, i.e., Lok Sabha and Rajya Sabha.

\section{READING 1}

In First Reading, a bill is introduced in Parliament. Maybe the Intro is opposed and consider for the voting in the House, but it very rarely happens that any debate is taken place during this stage. However, members may oppose the Bill if there is any sufficient ground to oppose. For example, If the Bill openly violates the Constitution of India.

\section{READING 2}

After the introduction of the Bill, the presiding officer in Lok Sabha and Chairman in Rajya Sabha, may refer the Bill to the standing committee for examination and take suggestions from that Committee like Committee of Environment and forest has invited suggestions on Civil Liability on Nuclear Damage Bill, 2010. Then it may be sent to the joint select committee of the two houses and circulated for eliciting public 
opinion. During second reading members may amend the Bill based on standing committee recommendations. However, the Government is not bound to accept recommendations.

\section{READING 3}

During third reading (passing) the House votes on the redrafted Bill. If passed in one House, it is sent to the second House where it goes through second and third readings again. The other House may reject the Bill and may the deadlock happened. Conditions of deadlock, may be happened cause of several reasons, such as:

1) One House passed the Bill, and the other rejected. ${ }^{1}$

2) When one House passes the Bill and other houses also passed but with an amendment and that amendment is rejected by the first House. ${ }^{2}$

3) When more than six months have elapsed from the date on which the Bill was received by the other House without the Bill being passed by it. ${ }^{3}$

4) When the deadlock happens, a joint sitting of both the houses is organised, and majority votes dissolve that. ${ }^{4}$

After both houses of Parliament pass a Bill, it is sent for the President's assent. He has the right to seek info about the Bill and also have the power to return the Bill to the Parliament for reconsideration. However, the President can send a bill for reconsideration only one time. If both the houses of the Parliament passes the Bill again, the President is bound to give his assent. ${ }^{5}$

After assenting of the President, the Bill is notified as an act and brought into force. The rules and regulations are made by executives who implement the act and are tabled in Parliament for consideration. Also, if any demerit seems in the act, then it is sent for Judicial Review.

\section{LEGISLATIVE DRAFTING \& LEGISLATORS}

Legislative drafting is a difficult, delicate art. It is the art of expressing in concise and clear language the ideas of other people. It is difficult enough to express one's own

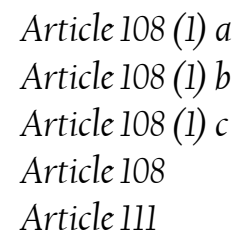


ideas. It is much more difficult to express other people's ideas. The difficulty is all the greater when there is a doubt about the person whose ideas one is required to express. Whose ideas do a legislative enactment express? Controversy, if not confusion, commences with this question. Are they the ideas of the Minister-in-charge of a particular Bill or the officer of the Ministry who instructs the draftsman or the collection of heterogeneous people constituting the legislature? Purists would at once point to the legislature. In legal theory, a statute always expresses the intention of the legislature. However, like all theories, this one is far removed from facts. It becomes crystal clear if we understand the mechanism of modern law-making. How is a Bill prepared? A legislative proposal is first conceived in the Secretariat. Sometimes the idea of the proposal emanates from the Minister himself. The proposal is examined in the administrative Ministry, but it is very rarely that, as required by the rules, a detailed memorandum of the proposal is prepared.

Generally, the officer in the administrative Ministry concerned with the legislative proposal rushes to the draftsman and asks him to produce a Bill. The draftsman insists upon precise instructions, but there is no time for such petty details; oral discussions follow. The draftsman produces some kind of Bill, hoping that he has correctly understood the instructions given to him. His instructors harbor the same hope. The Bill is then rushed through the legislature for want of time. Sometimes it emerges from the legislature in practically the same form in which it was introduced. The rule that law expresses the intention of the legislature applied in the good old leisurely days when laws were few, and the legislators had the time to scrutinize the laws carefully before passing them. In these days, laws are not made. They are manufactured.

The draftsman of today is supposed to prepare the maximum of laws within the minimum of time. To express the intention of some anonymous, mythical person whose identity is not easily established and to express that intention in language so clear that not only a reasonable man understands but a malicious man cannot misunderstand it. Says one judge, "This statute is so confused that it could not have been more confused, if confusion had expressly been aimed at." Lord Macmillan said about one section of the Trademarks Act that it was, "couched in the language of fuliginous obscurity."

Legislator and law-makers are generally the employees of the concerned Ministry charged with the responsibilities of drafting the Bill or are elected representatives of constituencies. In India, legislators or law-makers do not get any credit for the Bill drafted by them, and hence the job is often referred to as an "unthankful job." The job is not easy; many a time, legislators and law-makers are faced with challenges of conflicting interests and constraints. While drafting a piece 
of Legislation, they at the same time need to be aware of the current responsibilities vested in them, the portfolios they represent, the constituency that they represent, the interests of their political party and also the public interests of the country at large. The question thus arises: What should be the attitude of the Legislators in deciding the legislative policy of any Bill proposed to be introduced in Parliament. They are supposed to take into consideration all the conflicting interests and then decide the matter in the public interest.

\section{CONFLICT OF INTERESTS}

The different functions and responsibilities of legislators and law-makers give rise to different conflicts of interest. Accordingly, the articulation of appropriate standards of conduct and their supporting mechanisms must take these constraints into account.

Probably legislators face the widest range of potentially conflicting interests: personal, representational and other private pecuniary and non-pecuniary interests. Certain interests are personally inherent: as a resident of a town or province, as a parent, spouse, or child, as a female or male, as indigenous or non-indigenous and so on. Other interests arise from the representative role: as a member of the legislature, as representative of the electorate and as member of a political party. Further interests arise from outside activities as a member of a non-political organization, as a businessman, professional, farmer, grazier, or employee. These wide-ranging interests include, therefore, both pecuniary and non-pecuniary interests. Yet, despite all these potential conflicts, the Legislator must endeavor to act only in the "public interest."

The obligation to act in the public interest requires that precedence be given to the public interest at stake over the private and personal interests of the official. Representational interests raise their peculiar difficulties. For example, it raises the question of primacy between the party, the electorate and the nation. The UK Code of Conduct for Members of the House of Commons acknowledges at least two of these representational interests in Part II:

"Members have a general duty to act in the interests of the nation as a whole; and a special duty to their constituents."

One such recent example is THE GOODS \& SERVICE TAX, which illustrates the conflict of primacy between the duty to the nation and the political parties. Legislators \& Law-makers putting aside the political issue of sovereignty of the states and the Centre came forward and introduced the GST. Legislators from different 
parties and constituencies set aside their differences and acted for the greater good of the country. This ratifies the UK Code of conduct that the duty to act in the interests of the nation as a whole is supreme. The GST bill was passed by all the political parties reaching a consensus and not only from the parliamentary majority.

Indeed, it can be said that the primary function of a legislator is to reconcile these competing representational interests. This is what renders the position so onerous. At this point, cultural differences may accord different roles to legislators. For example, in societies, a legislator might be expected to represent particular groups who supported his or her election. Whereas in other societies, this might be viewed as unethical or unclear.

Professor Paul Finn summed-up the position before the New South Wales Parliamentary ICAC Committee in 1992:

"We have to realize that public office is based on a conflict between duty and interest. We would be deluding ourselves if we did not start on the premise that politics is concerned about compromise, partiality, and selfinterest behavior. The problematic question is where on the spectrum, does that behavior becomes unacceptable?"

Most discussion of conflict of interest focuses on the advancement of pecuniary interests. Indeed, at times a conflict of interest is defined solely by reference to the obtaining of a financial benefit. This narrow view of the conflict of interest avoids having to deal with the wide range of non-pecuniary interests, such as membership of a sporting, charitable, cultural, or environmental body or organization. Nevertheless, these interests are just as capable of raising a real or apparent conflict of interest which may distort government decision-making. Admittedly, there may often be a readiness to make such disclosure since the official obtains no pecuniary benefit and may revel in the disclosure of one's charitable pursuits. Nonetheless, to ignore nonpecuniary interests increases the likelihood of distortion of government decisionmaking.

How does a legislator decide whether to support proposed Legislation which restricts the logging of timber when faced with the following conflict of interests:

1) his or her political party supports a policy of environmental protection,

2) a significant part of the electorate represented depends on a forestry industry; and

3) Legislator's family operates a transport business in connection with that industry

The last consideration, a personal or private interest, should be declared and ought to be given no more weight than that to be accorded to an assessment of the effect of 
the proposed Legislation on those ancillary industries likely to be affected. Why is such a personal consideration ethically irrelevant? The reasons are:

1) the personal interest is too remote from the public interest; and

2) there is the risk that this interest will distort the process of deciding what is in the best interests of society as a whole.

As for the other two considerations, it is not merely a case of deciding which is the most important. Their resolution involves the weighing of the competing arguments. This may entail the reaching of a compromise, for example, to allow the forestry industry to operate within ecologically sustainable development guidelines.

A further potential conflict of interest is the elected representative's interest in being re-elected. Can a member of Parliament use one's official position to improve the chances of being re-elected? This raises the issue of Member of Parliament using his office for political purposes of the party to which Legislator belongs, as distinct from constituency matters. Several examples can be given in this respect, pointing out how Legislators set aside public purpose or interest to sustain the narrow interest of constituency or serve the interest of their political party.

During the voting procedure of the Goods \& Service Tax in the Lower House, Amendments were introduced that served the narrow interests of a particular constituency or a class of people. Comments and suggestions such as, "If you make the taxes 3/4th for the State and 1/4th for the Centre and the quorum required is $3 / 4 t h$, then you are effectively ousting the Centre from any discussion on taxation ${ }^{6 "}$ clearly shows the inclination of Law-makers to serve the interests of their constituency first. It also delineates the usage of official positions to increase the chances of getting re-elected.

One glaring example is a recent decision of the Delhi Government to allow Certain categories of industries to function in the residential areas of National Capital Territory of Delhi. This was in spite of the consistent stand taken by the Supreme Court of India that these industries pollute the city Area, and the citizens are deprived of pollution-free at resulting in endangering their health.

The main problem faced by the legislators in the state legislatures as well as in Parliament is their attitude to support narrow social problems of their own ethnic groups. In the Indian context: The Member of Parliament from Maharashtra will be inclined to support the interest of his State in supporting or rejecting any legislation tabled in Parliament. Likewise, the Members of Parliament from West Bengal, Odissa or Uttar Pradesh will try to gain mileage in supporting the interest of their states while deliberating on any legislation. It is this narrow interest of the Legislators that

6 Questions asked to Arun Jaitley at 7:02 PM. 
has become the subject-matter of great concern in passing and assessing Legislation in Parliament or State Legislature because furtherance of a narrow interest of individual State by legislators always conflicts with the interest of the nation as a whole. This narrow outlook of the legislators is highlighted when Legislations such as the Value Added Sales Tax (VAT) \& the Goods \& Service Tax (GST) came for consideration before the state legislatures.

"Questions have been raised about sovereignty and authorities of the State, are we surrendering that?" - concerns of Legislators during the discussion of reforming the tax regime of the whole country, State eccentric!

The problem of solving demands of the States vis-à-vis the national interest of the country is one of the most important aspects, which the Members of Parliament and the State Legislatures have to consider in-depth. Solving of this problem demands a better understanding of local conditions of all States, socio-economic upliftment of States and also the possible barriers that may be created by particular Legislation against the interest of a nation as a whole. There are several issues which assume great importance with reference to the interest of the individual States. The practice of manufacturing laws has led to large loopholes in the existing essential legislations, that creates a disparity between the State and the Centre. For example, to mitigate the loss of revenue for states on account of the introduction of GST, for the first five years, a compensation cess was brought in under section 18 of the 10lst Constitution Amendment Act. This guarantee, however, has not been inserted in the Constitution. A separate GST (Compensation to States) Act, 2017 was enacted, which provided, under section 8 , that:

"The compensation payable to a State shall be provisionally calculated and released at the end of every two months period, and shall be finally calculated for every financial year after the receipt of final revenue figures, as audited by the Comptroller and AuditorGeneral of India".

Now what happens if the Union does not release compensation cess at the end of every two months? A dispute ensues. Under Article 279A (11) of the Constitution, the GST Council must establish a mechanism to adjudicate between the Centre and

7 Questions asked to Arun Jaitley at 6.50 PM 
one or more states. However, even in the recently concluded 39th GST Council meeting, no steps were taken to create such a dispute resolution mechanism.

Certain people severely assailed the decision to form a new railway zone in the Railway Minister Constituency within three weeks of assumption of office by him. Supreme Court, however, held that formation of a new railway zone to meet the demands of backward areas is not by itself inconsistent with efficiency. More so, when it fulfilled the further criteria as to increase in traffic load and accessibility, the contention that efficiency would increase only if it could reduce the cost of administration and increase revenue was rejected. ${ }^{8}$ The decision was in the interest of overall interest of nation and people, and Members of Parliament, as well as Legislators, should rise above the party interest and take a considered view and should have supported the move.

In such a situation, it becomes imperative that the Members of Parliament and State Legislators come out of their narrow party interest and vote in furtherance of passing a Legislation which will be beneficial to all and would serve the interest of the citizens of the nation and should not be parochial to the interest of the individual State. The tendency of legislators to function as agents for a party or narrow interest of their constituencies rather than as trustees for people have often created voids in assessing and passing of legislative enactment.

Legislations are an advanced instrument of quick social change. It affects the State, the executive judiciary and the people of the country. The modern law-makers tend to confer more and more powers on the executive authority as Parliament. The Legislators have no time to assess the details of the Legislation and its effect on dayto-day working or life of the people Broadly speaking, legislative background or theory of any Legislation involves the study of the characteristic features essential to law and common to legal systems. It also involves an analysis of the basic elements of any legislation that distinguish it from other forms, rules and standards that cannot be described as legal systems.

The Executive Authority, as well as Legislators, as a part of constitution machinery, is duty-bound to resolve the problems of coordination between the three wings of democracy, namely, Executive, Judiciary and Parliament. There has to be a convergence of practices and opinions not only on the need for a solution to the problem faced by the people but also evolving a broad solution meeting the hardship faced by the people. The authority must see that the intended Legislation meets the objective of the greatest good of greatest numbers as enunciated in article 39 of the Constitution of India. Article 39 directs the Indian Federal and State Governments

8 Federation of Railway Officers Association v. Union of India, (2003) 4 SCC 289 
that the State shall direct its policy towards securing adequate means of livelihood and that the ownership and control of material resources of the come are so distributed as best to subserve the common good. ${ }^{9}$

\section{CONCLUSION}

In present world, Legislation is more potent than a hand-held weapon. While a weapon kills or destroys one or a few at a time, a wrong act of the Parliament or faulty Legislation can kill the livelihood of millions and take the country gushing into a downward spiral of democracy. It can be well established that it is essential that any discussion of safeguarding the integrity of legislators occur in a positive atmosphere which recognises the privilege and honour which attaches to those vested with the public trust. No assumption should be made that all who occupy the public office lack integrity. Instead, the desire should be to assist those in public office vested with that awesome responsibility to act always in the public interest.

Most mechanisms dealing with conflict of interest in relation to legislators and law-makers attempt to avoid or minimize a conflict of interest arising. In the hope that these avoidance mechanisms work, less reliance is placed on mechanisms which resolve a conflict of interest when one arises. But, we need more of mechanisms that resolve a conflict when it arises, as the former does not solve the issue, it just tends to postpone it whereas the latter permanently clear the road of legislators and thus truly enables them to perform their duties in the interest of their nation.

The issue becomes not what the officials can get away with, but can they justify their conduct for the interest of the nation? Essentially, it is another aspect of accountability and responsibility.

9 Article 39. Certain principles of policy to be followed by the State: The State shall, in particular, direct its policy towards securing

(a) that the citizens, men and women equally, have the right to an adequate means to livelihood;

(b) that the ownership and control of the material resources of the community are so distributed as best to subserve the common good;

(c) that the operation of the economic system does not result in the concentration of wealth and means of production to the common detriment;

(d) that there is equal pay for equal work for both men and women;

(e) that the health and strength of workers, men and women, and the tender age of children are not abused and that citizens are not forced by economic necessity to enter avocations unsuited to their age or strength;

(f) that children are given opportunities and facilities to develop in a healthy manner and in conditions of freedom and dignity and that childhood and youth are protected against exploitation and against moral and material abandonment 


\section{REFERENCES}

Civil Liability on Nuclear Damage Bill, 2010

The UK Code of Conduct for Members of the House of Commons

Personal Interview with Arun Jaitley at 7:02 PM.

Personal Interview with Questions asked to Arun Jaitley at 6.50 PM

the Constitution. A separate GST (Compensation to States) Act, 2017

Federation of Railway Officers Association v. Union of India, (2003) 4 SCC 289

Article 279A (11) of the Constitution, the GST 